\title{
The Significance of Internal Enterprise Resources from the Perspective of the Opinion Level of Top Managers of Czech Enterprises Operating in Service Sector
}

\author{
Jarmila Straková ${ }^{1, *}$ and Jan Váchal $^{1}$ \\ ${ }^{1}$ Institute of Technology and Business in České Budějovice, Department of Management, Okružní \\ 517/10, 37001 České Budějovice, Czech Republic
}

\begin{abstract}
This contribution focuses on the issue of internal enterprise resources in the service sector. The level of opinion in top managers is being observed, respectively what significance is being attached by top managers of enterprises operating in service sector to internal enterprise resources from the perspective of their current and future situation. Statistically significant differences between the meaning of internal resources nowadays and in the future are being analysed and indicated via the pair Wilcoxon test on a testing set consisting of 255 enterprises within the service sector from the whole of the Czech Republic. Within the evaluation of the current situation top managers assign a high importance mainly to employee standards, financial resources, the name of the enterprise, management quality, service and marketing portfolio. Evaluating prediction of enterprise internal resources and their importance's future development has pointed to a relatively high growth of significance in enterprise strategy, enterprise education, marketing, and information and communication systems. Statistically significant differences from Wilcoxon test have been proven in employee education, enterprise strategy, information and communication systems and marketing standards. Indicated internal resources will gain greater dominance in the future, and they may significantly influence the existence of enterprises operating in service sector.
\end{abstract}

Key words: top managers, service sector, internal enterprise resources, opinion level, evaluation

\section{Literary Review}

The economy of the Czech Republic has been characterized now for several years by permanent economic growth, shifting the Czech Republic among 5 EU countries with the best developing national economy. That is why it may be claimed that during the observed period $(2016,2017)$, during which a research survey of Czech enterprises focused on the area of strategic management and influence of enterprise environment was in process,

\footnotetext{
* Corresponding author: strakova@email.vstecb.cz
} 
profitable businesses prevail not only within service sector, while loss enterprises occur there in much lower amounts. The current economic development makes enterprises feel the omnipresence of positive development, enterprises do not appreciate a range of resources and factors from enterprise surroundings, but also the influence of globalizing and internationalizing processes on the constantly growing competitiveness of enterprises and their prosperity. At the same moment it opens an assumption for business subject preparation for a period of time with an opposing economic cycle, related to mainly internal enterprise resources. A change of economic cycle may be expected, according to both local and foreign economists' prognoses, within a time period of 3-5 years, however, the preparation for elimination of this change must be implemented in the current period of time, i.e. a time of economic growth.

The enterprise carries its activities out within certain environment which should be observed all the time. Enterprise surroundings may be defined as anything appearing beyond the fictional border of the enterprise as a technical and socio-economic system [13]. Dvořáček and Slunčík [2] as well as other authors classify enterprise environment into internal and external. According to Euremegbe [3], internal environment also includes situation factors within a specific enterprise. These factors are, largely, the result of a management process decision, mainly under management control. Pošvář and Erbes [11] consider harmonizing internal and external environment, with addition of management permanently analysing and observing its environment, determining important factors, possible future success, etc., to be the basic manager ability. The purpose of such analysis is to characterize the enterprise's strengths and weaknesses and to determine the enterprise's position on the market. Internal environment analyses contains the analysis of internal enterprise resources, on a general level we mean financial resources, human resources, material, and non-material resources (so-called resources of non-material character); at the same time, it also contains structure analysis in relation to environment change influence; system analysis, company culture analysis; analysis of its abilities, etc. Its result is determining the company's strengths and weaknesses $[1,7,15,16]$. Most local as well as foreign authors agree that optimal structure of internal resources is what becomes a base for creating competition advantage and reaching long-term prosperity $[4,6,8,16,19]$.

As the environment becomes more differentiated, its dynamic changes create circumstances for enterprises with correctly formulated internal resources, and ability to survive and prosper, while other, less adaptable enterprises may stagnate, become obsolete or lose their sense of integrality and identity [10]. Some research surveys $[14,18]$ have proven that the enterprise's ability to survive in competitive environment is affected straightaway by the value of its internal resources and ability to predict and use the opportunity, while others $[5,12]$ suggest that internal resources are even more important to keep competitiveness than external resources. Internal resources (such as human or technological capital) may, besides influencing competitiveness sustainability, may also become a source of knowledge for new product development [17]. Other research surveys warn about the fact that managers may be aware of new coming (or currently happening) changes in branches they are operating in, but they may not interpret these changes correctly. Often, they underestimate the meaning of given changes, and they may be waiting for too long as to react to them [9].

\section{Material and Methods}

Survey focused on the issue of strategical management, strategy, and influence of business environment on enterprises has been running since 2016. Data collection was done via a wide questionnaire survey. In 2017, the testing set consisted of 456 enterprises from the whole of the Czech Republic, enterprises were classified from the perspective of size 
categorization, sector differentiation, and spread of its influence. Nowadays, number of enterprises keeps growing, adding foreign companies from Russia and China, gaining a testing sample of Austrian and German enterprises is being planned.

For the purposes of this contribution, a testing set of 255 enterprises operating in service sector was chosen. A Wilcoxon's pair test was used. It is the statistical method which is used to test whether the mean difference of the figures of paired data is statistically insignificant or this difference is statistically significant medium. The mean value estimate for this test is made by median. We test the hypothesis $\mathrm{H}_{0}: \mathrm{x}_{0,5}-\mathrm{y}_{0,5}=0$ against the alternative $\mathrm{H}_{1}: \mathrm{x}_{0,5}-\mathrm{y}_{0,5} \neq 0$ at the significance level of 0.05 (i.e. reliability of $95 \%$ ).

\section{Results and Discussion}

\subsection{Significance of Internal Resources (current situation and prediction)}

The lower-mentioned results determine the significance of internal resources, as from the perspective of their current situation, as of prediction, respectively what significance top managers of enterprises operating in service sector assign to enterprise resources nowadays and in the future.

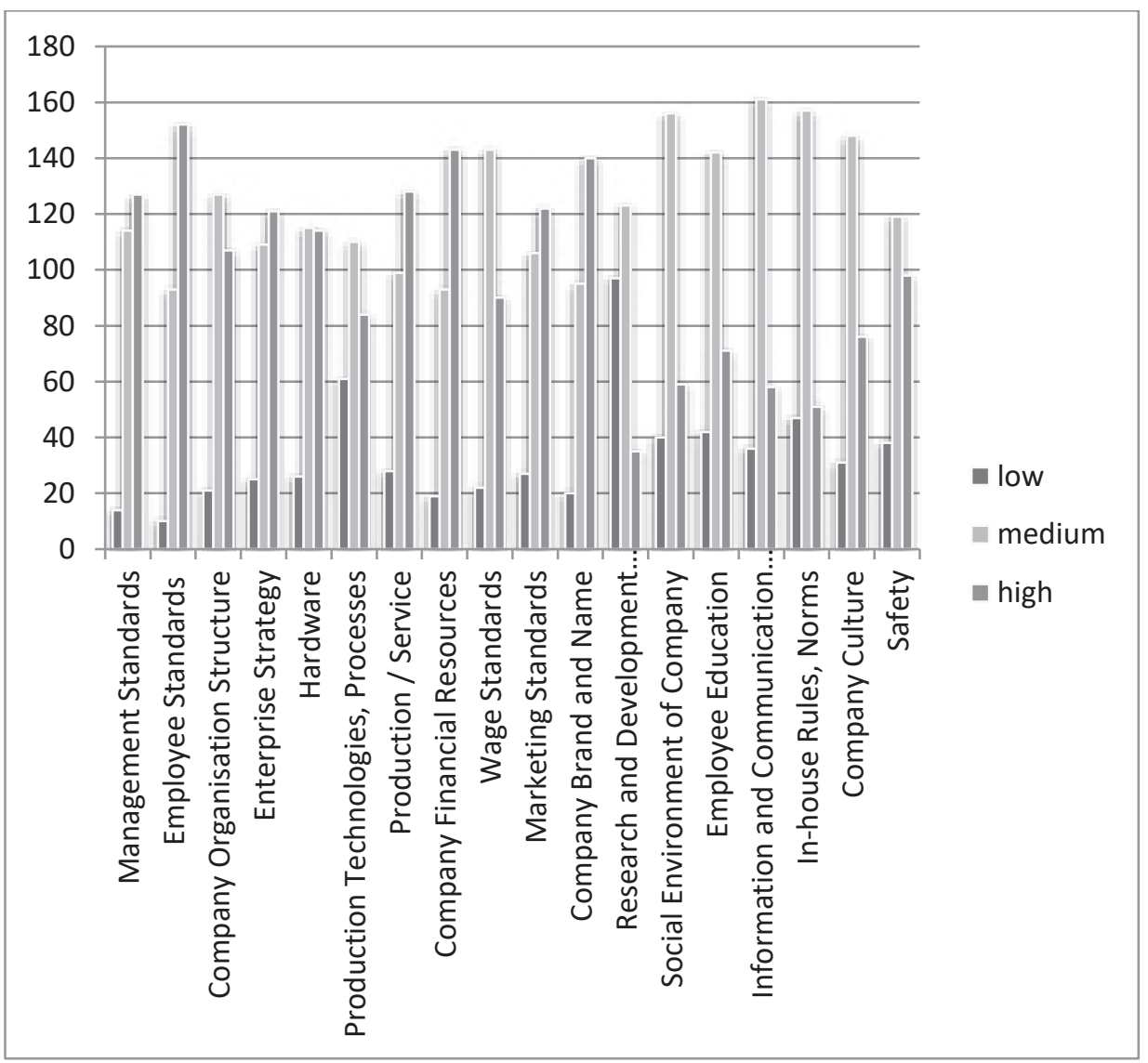

Fig. 1. Significance of Internal Resources from the Perspective of Level of Opinion of Managers of Enterprises Operating in Service Sector - the Current Situation.

Source: Authors. 
Top managers of enterprises operating in service sector assign, within their internal environment, dominant significance to the following: employee standards, financial resources, brand, and company name. At a smaller rate (even so evaluated as highly significant) they further state service portfolio, management quality, marketing, and enterprise strategy. From the perspective of current situation, the following resources may be considered decisive as well as limiting: financial security level, employee, management quality, service portfolio, marketing, and an accurately set strategy. Good reputation, respectively the name of an enterprise may be understood as a significant competition tool that, specifically within service sector, reaches intensity, because enterprises here move within highly competitive environment.

On the contrary, a very low significance is assigned to research and development by top managers, this situation may be considered a very negative finding. Research and development is still not appreciated by a great percentage of Czech enterprise managers, not only in service sector, but also in production and industry sector, where this situation is even more alarming. Often, the Czech business sphere strongly criticizes support of science and research from governmental side, a low representation of research organizations including universities, is also being criticized. This critique, however, has two levels, one really existing, at which inclusion of scientifically-research basis into the service sector innovation process is objectively insufficient, the second level relates to the willingness and readiness of enterprises themselves, operating in service area, at which enterprises operating here do not appreciate their receiver and new-solution, process, and technology implementer roles.

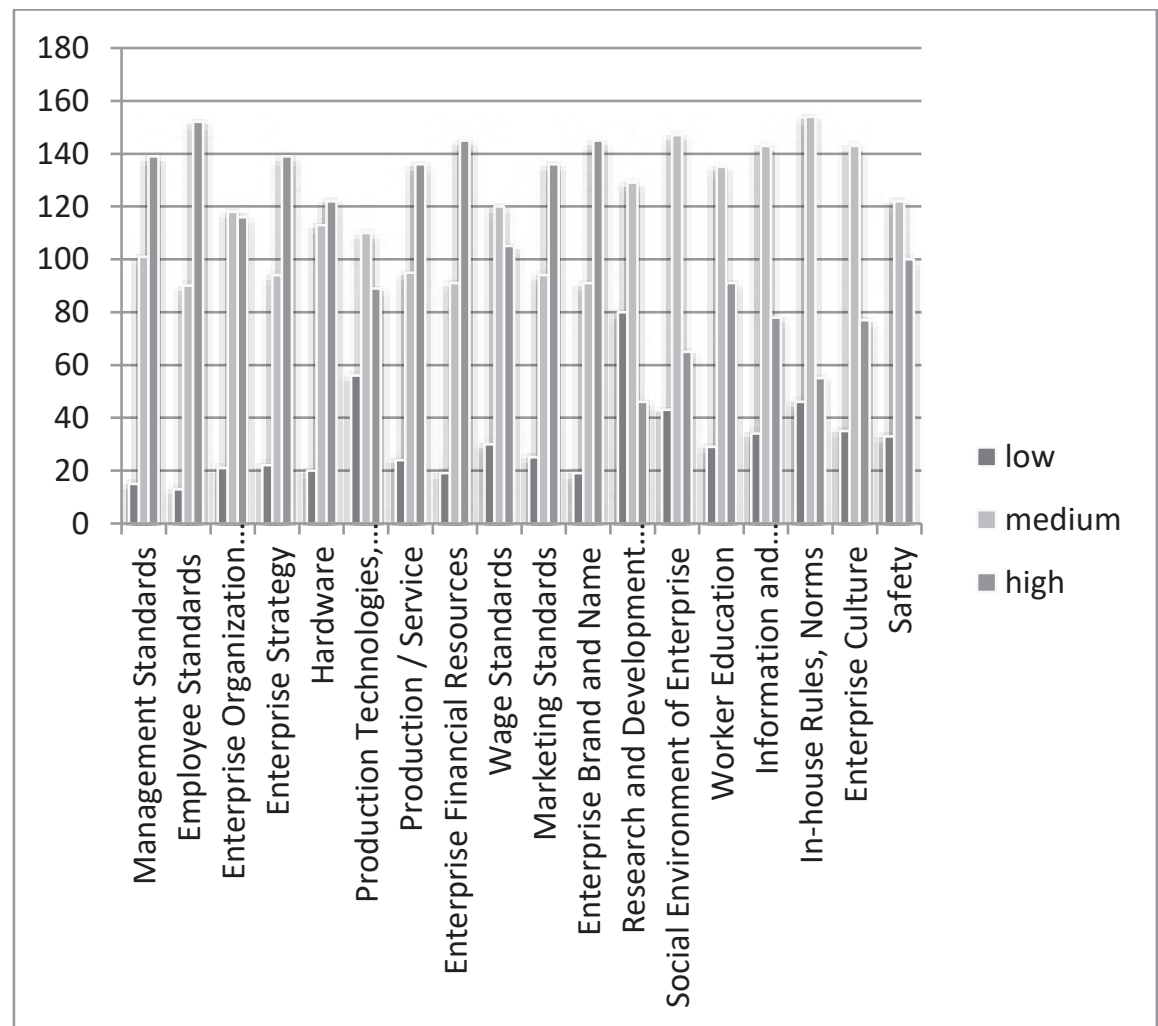

Fig. 2. Significance of Internal Resources from the Perspective of the Level of Opinion of Managers of Enterprises Operating in Service Sector - Prediction.

Source: Authors. 
From the perspective of prediction in the development of significance of internal resources from the perspective of their inclusion into a value-creating enterprise process, significant differences were not proven, compared to the current situation. Results are almost identical, the influence of positive economic development may be expected, as well as an underestimation of the option of a change in economic cycle, thus an underestimation of inner resource significance. A growth in enterprise strategy, marketing, and management quality growth should be noticed, and considered a positive finding. A relatively high growth of significance in enterprise education, information and communication systems is happening. It is a necessity to highlight the fact that internal enterprise resource analysis was already happening within the mentioned period of economic growth, which probably significantly influenced top manager perception, including their lowered ability of predicting expected changes in the future development of enterprise environment, and their impact on the structure of internal enterprise resources.

\subsection{Determination of Differences in the Significance of Internal Resources between the Current Situation and Prediction using Wilcoxon's Pair Test Analysis}

Table 1. Significance of Internal Resources - Current Situation (Service Sector).

\begin{tabular}{|c|c|c|c|c|}
\hline Current Significance & Arithmetic mean & Median & $\begin{array}{c}\text { Standard } \\
\text { deviation }\end{array}$ & Modus \\
\hline Management Standard & 2.44 & 2 & 0.60 & 3 \\
\hline Employee Standard & 2.55 & 3 & 0.59 & 3 \\
\hline Enterprise Organization Structure & 2.32 & 2 & 0.67 & 2 \\
\hline Enterprise Strategy & 2.36 & 2 & 0.71 & 3 \\
\hline Hardware & 2.33 & 2 & 0.71 & 2 \\
\hline Technology & 2.03 & 2 & 0.87 & 2 \\
\hline Service Portfolio & 2.36 & 3 & 0.75 & 3 \\
\hline Financial Resources & 2.47 & 3 & 0.68 & 3 \\
\hline Wage Standard & 2.25 & 2 & 0.65 & 2 \\
\hline Marketing Standard & 2.35 & 2 & 0.73 & 3 \\
\hline Brand and Name & 2.45 & 3 & 0.70 & 3 \\
\hline Research and Development Standard & 1.71 & 2 & 0.76 & 2 \\
\hline Social Environment of Enterprise & 2.05 & 2 & 0.67 & 2 \\
\hline Employee Education & 2.09 & 2 & 0.70 & 2 \\
\hline Information and Communication Systems & 2.07 & 2 & 0.64 & 2 \\
\hline In-house Norms, Rules & 2.00 & 2 & 0.66 & 2 \\
\hline Enterprise Culture & 2.16 & 2 & 0.67 & 2 \\
\hline Safety & 2.21 & 2 & 0.75 & 2 \\
\hline
\end{tabular}

Source: Authors. 
Table 2. Internal Resource Significance - Prediction (Service Sector)

\begin{tabular}{|c|c|c|c|c|}
\hline Future Significance & Arithmetic mean & Median & $\begin{array}{c}\text { Standard } \\
\text { deviation }\end{array}$ & Modus \\
\hline Management Standard & 2.48 & 3 & 0.62 & 3 \\
\hline Employee Standard & 2.54 & 3 & 0.61 & 3 \\
\hline Enterprise Organization Structure & 2.35 & 2 & 0.69 & 2 \\
\hline Enterprise Strategy & 2.44 & 3 & 0.72 & 3 \\
\hline Hardware & 2.38 & 2 & 0.69 & 3 \\
\hline Technology & 2.06 & 2 & 0.88 & 2 \\
\hline Service Portfolio & 2.42 & 3 & 0.71 & 3 \\
\hline Financial Resources & 2.48 & 3 & 0.67 & 3 \\
\hline Wage Standard & 2.27 & 2 & 0.73 & 2 \\
\hline Marketing Standard & 2.42 & 3 & 0.71 & 3 \\
\hline Brand and Name & 2.47 & 3 & 0.69 & 3 \\
\hline Research and Development Standard & 1.83 & 2 & 0.76 & 2 \\
\hline Social Environment of Enterprise & 2.07 & 2 & 0.68 & 2 \\
\hline Employee Education & 2.23 & 2 & 0.68 & 2 \\
\hline Information and Communication Systems & 2.16 & 2 & 0.68 & 2 \\
\hline In-house Norms, Rules & 2.02 & 2 & 0.68 & 2 \\
\hline Enterprise Culture & 2.15 & 2 & 0.69 & 2 \\
\hline Safety & 2.25 & 2 & 0.71 & 2 \\
\hline
\end{tabular}

Source: Authors. 
Table 3. Results of Wilcoxon's pair test between the significance of internal resources nowadays and in the future

\begin{tabular}{|c|c|c|}
\hline Future Meaning & V Value & p-Value \\
\hline Management Standard & 382.5 & 0.1334 \\
\hline Employee Standard & 688.5 & 0.793 \\
\hline Enterprise Organization Structure & 927.5 & 0.4128 \\
\hline Enterprise Strategy & 662.5 & 0.01339 \\
\hline Hardware & 961 & 0.09913 \\
\hline Technology & 1757 & 0.4653 \\
\hline Service Portfolio & 900 & 0.1449 \\
\hline Financial Resources & 614 & 0.8053 \\
\hline Wage Standard & 706.5 & 0.5566 \\
\hline Marketing Standard & 690.5 & 0.06898 \\
\hline Brand and Name & 718.5 & 0.4726 \\
\hline Research and Development Standard & - & - \\
\hline Social Environment of Enterprise & 1262 & 0.7519 \\
\hline Employee Education & 558.5 & 0.0004054 \\
\hline Information and Communication Systems & 880.5 & 0.02955 \\
\hline In-house Norms, Rules & - & - \\
\hline Enterprise Culture & 573.5 & 0.7005 \\
\hline Safety & 554 & 0.3772 \\
\hline
\end{tabular}

Note: Factors (research and development standard and in-house norms, rules) were not tested because the average value of the current level of these internal resources was lower than the value 2 (significant internal resource).

Source: Authors.

Table 3 contains the results of Wilcoxon's pair test between the given significance of internal enterprise resources nowadays and in the future. Significant statistical differences have been indicated in employee education, enterprise strategy information and communication systems, less significant in marketing standards. All of the stated resources are significant for enterprises operating in service sector, and they significantly influence their current as well as future existence within more and more intense and sharpening competition environment. These internal resources are going to gain still greater significance, especially during the period of economic decrease in national economy performance. It may be claimed that the results obtained fully correspond to the service sector characteristics.

\section{Conclusion}

Research survey has brought and suggested a few valuable findings that may be taken into account within enterprise strategic management in business practice for service sector. The solution outcomes allow the following conclusions: 
- Internal enterprise resources may be considered a starting base for the existence itself, development and competitiveness of enterprises within service sector, and that is why enterprise top managers should be paying corresponding, i.e. greater attention. A range of current managers is not, unfortunately, aware of this fact, the causes of this may be observed in the fact that, as it has already been suggested in Results and Discussion, Czech economy has found itself, now for a few years, in a period of economic growth, and internal resources, as well as mid-environment and macro-environment factors, remain usually unrecognized. A change in economic cycle is, however, inevitable, and managers should definitely not underestimate its preparation, they should take into account the fact that internal resources, their quality and optimal structure might mitigate and eliminate negative impacts related to this future change.

- Employee standard, financial resources, market brand and enterprise name may be considered the 'core' internal resources in service sector in the current period, service portfolio, management quality, marketing, and enterprise strategy should be considered as additional, but still important. The absence of research and development factor is warning, and it requires a solution from the state's side as well as from the side of enterprises themselves.

- Within significance testing in differences between the current and future situation among internal resources in service sector enterprises, statistically significant differences were proven in enterprise education, strategy, information and communication systems, and marketing. The named internal resources respond to the service characteristics.

- The service sector requires relatively 'little capital', the more is its attention focused on human resources and their development. In the Czech Republic, unemployment has historically been the lowest. Enterprises get into trouble with lack of qualified available workforce, they start to look for reserves within internal resources and pay more attention to enterprise education.

\section{References}

1. C. Capon, Understanding the business environment: inside and outside the organisation. Prentice Hall/Financial Times, NY, (2009)

2. J. Dvořáček, P. Slunčík, Podnik a jeho okoli: jak přžít v konkurenčním prostředí C. H. Beck, Prague, (2012)

3. G.O. Euremegbe, Impact of business environment on organization performance in Nigeriaa study of union bank of Nigeria. ESJ, Special edition, 478-494, (2015)

4. R.T. Frambach, E.J. Nijssen, Creating Customer Value Through Strategic Marketing Planning. Kluwer Academic Publishers, London, (2001)

5. G. Hawawini, V. Subramanian, P. Verdin, Is Performance Driven By Industry- or Firm-Specific Factors? A New Look at the Evidence. Strategic Management Journal, 24, 1, (2003)

6. Ch.W.L. Hill, G.R. Jones, Essentials of strategic management. SouthWestern/Cengage Learning, Mason, (2009)

7. T.R. Jain, M. Trehan, R. Trehan, Business Environment. VK Global Publication, New Delhi, (2014)

8. D. Jakubíková, Strategický marketing. Grada Publishing, Praha, (2008).

9. Z. Jovanovic, Management and changes in business environment. Ekonomika, [Економика], 61, 2, 143-151, (2015)

10. K. Motamedi. Resilience in dynamic complex environments, 131-141. 6th Business \& Management Conference, Geneva, (2017) 
11. Z. Pošvář, J. Erbes, Management I. MZLU, Brno, (2008)

12. R. Rumelt, How Much Industry Matter? Strategical Management Journal, 12, 167-185, (1991)

13. M. Synek, Manažerská ekonomika. Grada Publishing, Praha, (2003)

14. J. Wang, Y. Ying, Internal resource, external environment and competitive advantage of enterprises - Empirical study based on Hubei province manufacturer, Proceedings of the International Conference on E-Business and EGovernment, ICEE 2010, 2930-2933, (2010)

15. I. Worthington, Ch. Britton, The business environment. Pearson Education Limited, UK, (2010)

16. M. Zamazalová, Marketing. C. H. Beck, Praha, (2010)

17. J. Zhang, W-P., Wu, Social capital and new product development outcomes: The mediating role of sensing capability in Chinese high-tech firms. Journal of World Business, 48, 539-548, (2013)

18. J. Zhang, W-P., Wu, Leveraging internal resources and external business networks for new product success: A dynamic capabilities perspective. Industrial Marketing Management, 61, 170-181, (2017)

19. R. Zuzák, Strategické řizení podniku. Grada Publishing, Praha, (2011) 